\title{
Reservists and Veterans: Viewed from Within and Without
}

\author{
James Griffith, Vince Connelly, Sergio Catignani, and Eva Johansson
}

\section{Contents}

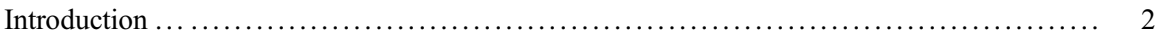

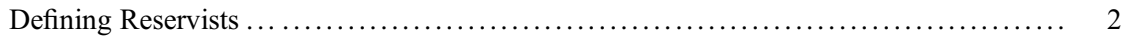

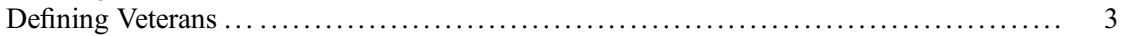

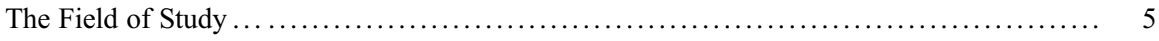

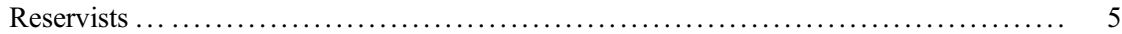

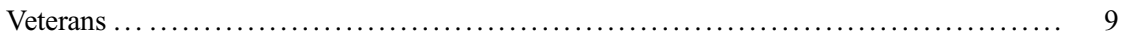

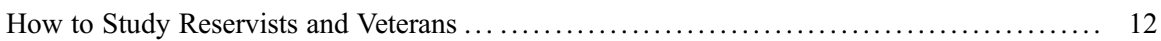

Substantive Scope of the Field .......................................... 13

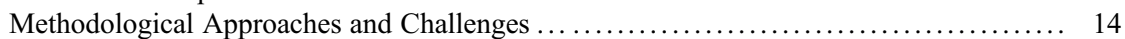

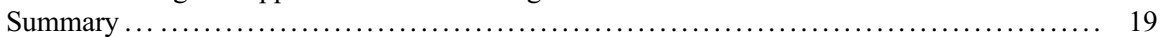

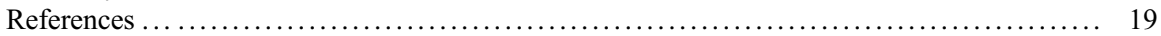

\section{Abstract}

This chapter describes two important groups relative to military service - reservists and veterans. Definitions are provided regarding who is a member of each group. A summary of past and current research findings for each group is provided. The summary is organized by investigative topics or themes, which provide the current scope of the field for reservists and for veterans.

J. Griffith $(\bowtie)$

National Center for Veterans Studies, University of Utah, Salt Lake, UT, USA

e-mail: jhgriffith@comcast.net

V. Connelly

Psychology, Health and Professional Development, Oxford-Brookes University, Oxford, UK e-mail: vconnelly@brookes.ac.uk

S. Catignani

Department of Politics, Exeter University, Exeter, UK

e-mail: sergiocatignani@gmail.com

E. Johansson

Department of Security, Strategy and Leadership, Swedish Defence University, Karlstad, Sweden e-mail: eva.johansson@fhs.se 
Finally, approaches to the study of reservists and veterans are described, along with challenges - both substantively and methodologically - for future research studies. These serve as fertile areas for improvements and investigations in future research studies.

\section{Keywords}

Military reservists $\cdot$ Military veterans $\cdot$ Deployment $\cdot$ Well-being and health · Family $\cdot$ Transition $\cdot$ Civic engagement

\section{Introduction}

Reservists and veterans are the subject of this chapter. Why are these two populations treated together, when by all appearances seem so disparate? Reservists and veterans are at times wholly integrated in the military - in the case of reservists, when activated and deployed, and in the case of veterans, during prior military service. However, when reservists serve in their /traditional part-time role and when veterans leave military service, they are less integrated in the military and resemble civilians, and consequently, they represent very unique military populations. Members of these populations, then, fall in between complete and partial immersion in the military, and as such, reservists and veterans can be studied as groups along the continuum of military institutionalization, compared and contrasted to full-time military servicemembers and civilians, informing aspects of the civilian-military gap (Karsten et al. 2002). Here, we present past and current topics of research interests for each population - some common to each population and others not. Investigative topics take into account perspectives of reservists and veterans themselves as well as those of the general public concerning these two populations, and hence, the chapter title - viewed from within and without. A summary of findings relative to these investigative topics offers background and direction for future research studies. Specifically, we offer considerations for content and methods of future studies of reservists and veterans.

\section{Defining Reservists}

Broadly, reservists are defined as those who participate in the military part-time as opposed to full-time. (Those who serve full-time in the military are often referred to as "regulars" or "active duty" personnel.) The number of reservists in a country's armed forces varies considerably from country to country, in addition to the proportion of the country's total force. Where there is compulsory military service, nearly everyone in the population is a reservist, as is the case for Israel, Switzerland, and Finland. Sweden re-instituted conscription in 2018, due to difficulties in staffing on a voluntary basis. Every year about 4,000 men and women are called up for service, increasing up to 8,000 by 2024 . 
For countries having voluntary military service, the numbers of reservists are much lower, due to the fact fewer are needed to staff reserve units, as is the case for the United Kingdom (UK) and the United States of America (USA). In the USA military, reservists $(800,000)$ comprise over half of the total military force $(1.3$ million) (Governing 2017). In the UK, there are approximately 35,000 active reservists; reservists make up some $25 \%$ of the force. In Canada, reservists make up 35\% of the force (Ministry of Defence 2011). In Sweden, reservists make up 36\% of the force (Armed Forces Annual Report 2019), including the Home Guard.

The frequency and duration of part-time military service differ among reservists, within countries and between countries. Some reservists, here called "active reservists," join and incur obligatory periods of military service. For example, in the USA, recruits incur an eight-year obligation. Active reservists are usually assigned to specific units and attend training periods during weekends (usually one weekend a month), evenings, and concentrated periods of training (often up to two weeks annually). In the USA, these are called "traditional" or "Troop Program Unit" reservists. For a detailed discussion of the USA reserve force, see Federal Research Division (2019). Other reservists participate in the reserve force less regularly. Such reservists are required to complete a sequence of training specific to their military occupations and enlisted/officer progression. These reservists often do not have specific units of assignment and, therefore, are not required to attend regular monthly assemblies or annual training. Examples of such reservists are members of the USA military's Individual Ready Reserve (IRR), Individual Mobilization Augmentation (IMA), and inactive reserves. Members of the UK ex-Regular Reservists are another example. These reservists have no specific requirements for military service. These personnel are full-time soldiers who have left the service but their contract requires military service only in rare cases of specific national emergencies (Connelly 2018). Similarly, reservists of the Finnish Army complete a period of full-time conscript service. They subsequently return to civilian life but remain members of the reserve force and can be called back in emergencies. In most countries, during threats to national security, higher headquarters may call reservists of any type to active duty - all together with members of the unit or individually and small groups in order to fully staff other reserve or active duty units (called "backfilling" or "crossleveling").

\section{Defining Veterans}

In most countries, veterans are generally defined as those who have served in the military and have subsequently been discharged under favorable or honorable circumstances. Veterans include those who have served anywhere from as little as one day to many years. Veterans also include those who have served full-time and part-time as reservists. Veterans are often associated with specific period identity, for example, those who have served in combat areas are called "combat veterans" or specific to wars - veterans of World War II, Korean War, Vietnam War, or Operation Iraqi Freedom (OIF) and Operation Enduring Freedom (OEF). In the UK, the 
majority of the population tends to use the term veteran for those who have served in either of the World Wars (Burdett et al. 2012). Similarly, in Sweden, a distinction is made between those military personnel who have served either in-country or out-ofcountry (the latter, labeled as "mission abroad veteran"). The distinction is, among other things, due to the Swedish government decision in the 1990s to leave the traditional invasion-based defense in favor of a defense with greater emphasis on multinational missions abroad.

The number of veterans in the general population has much to do with how many have served in the military. Countries having compulsory military service have large proportions of the population who have served and as a result have many veterans. In contrast, countries having voluntary military service have fewer veterans, especially when the military is small relative to the general population. For example, the USA military has changed from compulsory military service to volunteer military service in 1973. This change reflects the number who have served and later become veterans. Among the 1930 birth cohorts, nearly half of the males in the USA was military veterans, contrasted to the Millennial cohorts (born 1981-1996), with about $4 \%$ of all males being military veterans (Pew Research Center 2019). The highest number of living USA veterans served in the Vietnam War (6.8 million), followed by the Gulf Wars (5.6 million, defined by 1990 to present), peacetime (4.3 million), Korean War (1.8 million), and World War II (930,000) (Parrott et al. 2019). In the UK, the Ministry of Defence (2019) estimates that in 2016 there were 2.5 million veterans. Since 2001, UK government policy officially recognizes any ex-servicemember as a veteran when the member has served for at least one day in the military and has drawn a day's pay. Compared to other countries, this description is the most inclusive definition of a veteran, resulting in problems of providing effective support to such a large population of veterans (see Ashcroft 2014).

Veterans are disproportionately men, primarily due to few women participating in past major wars. More recently, women have been included in the militaries of many countries. In the USA, women veterans have increased seven-fold from World War II to present (Clever and Fisher 2017). Of the 22 million veterans in the USA in 2015, 2 million are women. Investigative topics of women veterans resemble those of men veterans (e.g., mental and physical health problems, health care access, and homelessness). There are, however, a few exceptions. Women veterans often face additional challenges when deployed - increased worries and concerns about family members' care and greater likelihood of sexual harassment and assault (Clever and Fisher 2017).

The transition from military service to civilian life can be more difficult for women, mixing various roles of household provider and care provider to spouse and children in "unhealthy mix" (Disabled American Veterans 2014, p. 10). Just as civilian women but different from men, both veteran and nonveteran, women veterans face gender-specific health problems, including obstetrical and gynecological care, heart disease, and cancer. 


\section{The Field of Study}

We define the field of study for reservists and veterans by recurrent investigative topics of the research literature. In this section, a summary of findings relative to these investigative topics or themes is provided first, for reservists and second, for veterans.

\section{Reservists}

Recent and current topics of investigation relate directly to the changed role of the reserve force. In the last decade, the reserve force in many countries has gone from a strategic force, largely static, to an operational force, largely dynamic. An historical overview of the reserve force after World War II provides an understanding of the current reserve force structure and prevailing investigative areas. After World War II, military forces of Western allies remained relatively large, though much of the force was re-allocated to the reserve force. Reservists acted as a deterrent to Soviet and Chinese aggression, called containment (Drew 1999). Reservists comprised a large pool of military personnel, serving part-time, and thus saved substantial costs compared to a large full-time force. When threats were discerned, reservists would be mobilized; this then would be an indication of serious defensive action, short of nuclear attack (Drew 1999). Such was the case in the Cuban missile crisis (1962) when the USA mobilized several thousands of reservists. However, this was the exception. This period, called the Cold War, spanned from 1945 to the fall of the Berlin Wall in 1991.

Costs associated with an active duty military force necessitated further downsizing and moving units to the reserve force. For example, the USA Total Force policy (1980) reduced the size of the active military by moving units to the reserve force, in particular, combat support and combat service support units (Carafano 2005). For any large-scale military operation, reservists would have to be mobilized and deployed. This use described an "operational reserve" (Whitlock 2006). This change from strategic force to operational force characterizes the militaries of many Western countries. For example, in Sweden the 2015 Commission on the Manning System of the Military Workforces determined a reserve force of at least 23,000 members, double that of its size today. The changed role of the reserve force has made reserve military service more demanding, with more frequent and prolonged deployments. These events affected who would serve and how and the emergence of several areas of investigations.

Reservists' readiness. Deployments meant reservists needed to be ready, individually and collectively. Reservists generally serve, in the USA case, 39 days a year. Reserve officers in Sweden serve, at the most, 1,095 days (3 years) during an 8-year period. Activities and amount of days are regulated by a servicemember's plan, established on a yearly basis. Since reservists are part-time and have more limited training periods, reservists when activated often take time to get up to standards of individual and collective readiness as full-time military personnel. This is not 
surprising, as observed in the first large-scale mobilization of USA reservists during Operation Desert Storm (ODS, 1990-1991). Approximately 230,000 USA Guard and Army Reserve personnel were mobilized for active duty military service. More than 100,000 were sent to the Persian Gulf, and the remainder served stateside to replace departing full-time military units (Nelson et al. 2001). Significant noted shortcomings were units having carried personnel on the rolls but who had not been attending monthly assemblies and units having personnel who were present in units yet had to be trained (e.g., attend basic training or advanced military occupational specialty training) or had not met physical fitness and medical requirements (e.g., overweight, unable to pass the Army Physical Fitness Test, had dental problems, etc.) (Orvis et al. 1996). Other inadequacies included shortcomings in individual job skills and combat preparation, utilization during weekend drills (having received task assignments), noncommissioned officer (NCO) and officer leadership, and collective training (General Accounting Office 1992). Such findings made readiness a major investigative focus.

Accomplishing readiness on a part-time basis (a weekend a month and two weeks annual training) is challenging. Readiness is often dependent on effective use of monthly drills and annual training, frequency of realistic training, and availability of modern equipment. These efforts compete with keeping costs of such activities lower than those of the full-time force, and thus, risk reserve readiness. Additional training periods are also frequently needed for leaders and key personnel. These preparations compete with reservists' families and civilian employment, making reserve military service increasingly challenging. On the positive side, reservists bring many civilian specialist skills, not available among those in the full-time military force. These skills are highly-valued, being novel and often needed in deployment, in addition to reinforcing occupational skills of military specialties (see Bury 2019).

Reservists' health. Well-being of reservists has been a past and continued investigative focus, particularly for those reservists deployed. Studies show that during deployment reserve and active duty soldiers generally do not differ in posttraumatic stress disorder (PSTD) and related symptoms (U.S. Department of Defense 2008). During postdeployment, deployed reservists report higher rates of posttraumatic stress disorder (PTSD) and related symptoms (1) when compared to deployed active duty personnel (Milliken et al. 2007; Schell and Marshall 2008); and (2) when examining differences between deployed and nondeployed personnel by component (Hotopf et al. 2006). Rates of PSTD and related symptoms (or changes in symptoms of cohorts across time, immediately after deployment and later) are greater for deployed reservists than for deployed active duty soldiers (Milliken et al. 2007), in particular, for those who report stress conditions right after deployment (Smith et al. 2008). Higher rates of PTSD and related symptoms among reservists appear later after returning from deployment, 3 to 6 months later (Milliken et al. 2007; Thomas et al. 2010), and up to four years later (Smith et al. 2008). These findings have spurred efforts to better screen reservists after deployment and during postdeployment (Griffith and Bryan 2017). Efforts also include methods to increase 
better access to behavioral health care and methods to lessen stressful events associated with deployment for reservist and their families (e.g., predictable deployment schedules, reintegration programs, etc.).

Reservists' families. An area of investigation has been spouse and family attitude toward reservist's military service. USA studies show that extended training and deployment relate to negative attitudes of reservists' family members and employers (Grissmer et al. 1992; Kirby 2000). Such attitudes captured after the First Gulf War (1990-1991) related to reservists' less willingness to continue reserve military service (Griffith 1995). In the USA, during the height of the Iraq and Afghanistan wars, over a third of the ground combat forces was reserve military personnel. For many reservists, this was the first time of prolonged deployment (over 12 months), and for some, repeated deployments. These experiences are difficult adjustments for families and for servicemembers - evident from studies of deployment and postdeployment experiences (Griffith 2019). Indeed, UK reservists who judged the military support to their family as being poor when deployed were less inclined to remain in reserve military service (Dandeker et al. 2010).

A more recent focus has been specific aspects of family members' adaptation during deployment. Reservists and their families make extraordinary adjustments during deployments, such as having significant changed roles in the family affecting household management (MacDermid 2006) and parenting children (Rentz et al. 2007) and having to make difficult income adjustments (Kline et al. 2010). These adjustments relate to reservists' deployment stress. Studies examining stress symptoms among reservists point to unique deployment stress, such as worries about spouse, children, household chores, finances, etc. (Castenada et al. 2009; Erbes et al. 2008). The Swedish military, in particular, has pursued a line of research (Olsson and Olsson 2019; Weibull 2009), called "dialogical participation action research" (DPAR), aimed to develop methods for servicemembers and their family to cope with stressors, especially those associated with international deployments.

Reservists' civilian employment. Civilian employment is the primary livelihood of reservists and presents another unique aspect of reserve military duty. Civilian employment of reservists is most affected by deployments, often involving prolonged periods of active military service and absence from civilian work. After deployment, reservists have to re-establish relationships with their civilian employers and work, unlike active duty personnel. Civilian employers are not always understanding of reservists' military activities. While there are numerous examples of this being done without problems, there are also examples where reservists have been given lesser jobs, laid-off, etc., even when contrary to national law (Castaneda et al. 2009), causing reservists additional worries. Some countries (e.g., USA) guarantee the same or similar jobs to reservists before having been deployed. Re-employment and prevalence of postwar adjustment problems (Griffith 2010), including suicide (Griffith 2012), has brought greater attention to financial hardships of reservists who are deployed, such as pay equity while deployed and subsequent re-employment after returning. Re-employment inequities observed among USA reservists have resulted in several initiatives to provide more certainty to reserve deployments and support for reservists, their families, and civilian 
employers (e.g., Army Force Generation policy for deployment predictability (Whitlock 2006), The Yellow Ribbon Reintegration Program (U.S. Department of Defense 2008) for Family Support Groups (FSG), and Employer Support of the Guard and Reserve (ESGR) programs.

Reservists' recruitment. The changed role of the reserves, from a strategic role to an operational role, has occurred in many countries, in particular, in the context of a volunteer force. This meant that the reserves had to recruit sufficient personnel to staff units. And as already noted, reserve military service has become increasingly demanding. For many countries, staffing reserve units has been problematic, especially for military specialties (e.g., medicine, engineering). In addition, prevailing negative views of reserve military service in the wider community hurt staffing of reserve units (Connelly 2019). These problems have given rise to studies of how to recruit reservists.

To meet personnel staffing requirements, countries have developed marketing plans that included incentives, such as bonus money, educational benefits, job training, etc. For example, when the USA first started voluntary military service (1973), recruiting for the reserves was difficult (Schmitz 1990). With the rising costs of college tuition and increased emphasis on college attendance in the 1970s and 1980s, offering educational assistance was an effective strategy to recruit. College-bound youth then became the primary market for the USA Army Reserve (Schmitz 1990). These recruits, along with many others, join the Army Reserve for extra pay and job skill training (Griffith and Perry 1993). However, such recruits often leave military service when mobilized and deployed, as the case during Operation Desert Storm (Griffith and Perry 1993). In addition, recruits who join for primarily tangible benefits (e.g., bonus money, educational benefits, and job training) are frequently less willing to report for mobilization and to stay in military service (Griffith 2008). During more recent wars in Iraq and Afghanistan, the USA had great difficulty in staffing units, often stopping soldiers from leaving after the end of obligatory service, offering large bonus money for joining or staying in military service, and allowing medical, moral, and mental waivers for new entrants (Gallaway et al. 2013). Western militaries relying on volunteers report similar experiences. The Sweden's Defence Policy (2016-2020) stressed the importance of reserve officer recruitment to achieve warfighting needs of units. Initial training of tactical reserve officers is conducted through in-house training and education for those who already have or will acquire a civilian academic degree. While these efforts have been somewhat successful, studies suggest that such recruits often have lower levels of commitment - less willing to report for mobilization and less likely to remain in reserve military service beyond initial commitments (Griffith 2008).

Reservists' identities. Traditionally, reserve military service involves intermittent contact with the military, unlike active duty military service. When activated and deployed, reservists leave their families and civilian work and return once deployment ends. Describing the way in which the reservist relates to these aspects of military service, called identity, has been a topic of investigation. Depictions often center on conflicting demands between military service and civilian life. One of the earliest descriptions of the reservist is Ben-Ari's (1989) metaphor of "masking." 
This term describes how a reservist, largely a civilian, comes to terms with conflicting demands of military service. Lomsky-Feder et al. (2008) describe reservists as "transmigrants." This label characterizes the numerous transitions required of reservists - most often a part-time endeavor complicated by civilian employment and family, but also full-time having to mobilize and be deployed, and transition back to part-time military service. Vest (2012) describes three processes whereby the reservist incorporates experiences (i.e., multiple belongings and possible identities) into sense of unity of self-identity. Use of these processes is different between deployed and nondeployed reservists and have implications for postdeployment adaptation. For example, deployed USA Guard identified more strongly with military service with greater internalization, in particular, deployment experiences. Griffith (2011a) proposes several identities most characteristic at different time periods in the USA military - 1945 to present. Each identity corresponds to a set of expectations for reserve military service. Some identities are congruent with the demands of reserve military service (e.g., in modern times, "soldier warrior," versus in less modern times, "weekend warrior") and thus are more likely than others to better meet current and emerging demands and to cope with deployment stressors. These approaches are useful in understanding the processes individual-level mechanisms and adaptations when activated and deployed (Griffith 2011a). Identity can also be influential in mental health vulnerability in both military and civilian life through engendering a stronger sense of agency among reservists who then can more successfully negotiate demands of military service and civilian life. Identities are also useful in determining those applicants most suited for modern reserve military service - most willing to serve especially when mobilized and deployed (Griffith 2011b).

\section{Veterans}

As reservists above, we define the field of study for veterans by recurrent investigative topics found in the research literature. This section provides a summary of findings relative to these investigative topics or themes. An excellent and very recent source for veterans' issues and studies is the two volume book, The civilian lives of U.S. veterans: Issues and identities (Hicks et al. 2017).

General health. A major topic of interest for military veterans has been their general health after leaving the military, particularly those who served in combat areas. This concern stems from veterans being disproportionally overrepresented in psychological and substance abuse disorders relative to the general population (Substance Abuse and Mental Health Services Administration 2019). Between 4\% and $17 \%$ of USA veterans have been diagnosed with PTSD (Richardson et al. 2010). Veterans also have twice the mortality rate for accidental drug overdose compared to the rate in the general USA population (Bohnert et al. 2011). In recent years, USA military veterans account for about a third of all suicides in the general population (Jaffe 2013). 
Such findings are not entirely consistent across countries. Fear et al. (2010) observed few enduring psychological challenges among UK military personnel after return from deployments. While there has been some growth in numbers of UK military personnel displaying mental health difficulties postmilitary service overall, the percentages remain small compared to the USA (Stevelink et al. 2018). Swedish veterans who were deployed do relatively well, both psychologically and physically during postdeployment (Larsson et al. 2018a, b; Michel 2005). A cohort study (Pethrus et al. 2017) showed, for example, that Swedish military veterans do not differ from nondeployed risk for suicide or mortality. Other studies have shown veterans in Sweden generally do better compared to nonveterans in the general population (Larsson et al. 2018a, b). A more recent line of Swedish veteran studies has focused on the accumulated effects of daily hassles. Such hassles have shown stronger relationships with physical and psychological symptoms than major stressful episodes or chronic stressors, in addition to the potentially buffering effects of daily uplifts on personal distress (Larsson et al. 2016). Even so, public perceptions, some accurate and others not, have contributed to the view that many veterans, in particular in the UK and the USA, suffer from problems (Ashcroft 2014). The media often report the incidence of mental health issues among veterans, which are misleading. For example, suicide rates postconflict are often compared with rates of combat deaths, adding to stereotypical beliefs about adjustment among all veterans (Connelly and Burgess 2013).

Transition from military service to civilian life. Some researchers relate negative health outcomes of veterans to the difficulties of transitioning from military service to civilian life, often requiring significant adjustment (Romantuk and Kidd 2018). Several studies report military veterans having some form of reintegration difficulty (Griffith 2015; Sayer et al. 2010). These include having poor family relationships (Karstoft et al. 2015), being unemployed (Sayer et al. 2010), having troubled finances (Pew Research Center 2011), being of poor physical and psychological health (MacLean et al. 2014), and being homeless (Tsai et al. 2016).

Changed identity associated with military life and then civilian life might explain some of these negative life outcomes for veterans (Romantuk and Kidd 2018). The military is a closed or "total institution" (Goffman 1961), having a defined structure and hierarchy reinforced by explicit procedures and an implicit culture. The military organization provides members with purpose, individually and collectively, and through its team-oriented culture, members shared social bonds or comradery. When discharged, military veterans often describe a loss of purpose and meaning in what they do (Ahern et al. 2015; Kulka et al. 2015). This loss has been related to poor preparation for transition out of the military (Kulka et al. 2015; Walker 2012). Veterans experience civilian life as less structured, less purposeful, and less communal, often associated with emotional distress (Burkhart and Hogan 2015). Those who have left military service early or prematurely are especially more at-risk for health and adjustment problems than those who serve a full career (Cooper et al. 2018). Several other factors likely contribute to poor adjustment among veterans, including preservice factors such as childhood adversity (Murphy and Turgoose 2019), planned versus unplanned departures (Spiegel and Shultz 2003), postservice 
civilian work and family experiences (Taylor et al. 2007), and social networks which no longer serve effectively (Hatch et al. 2013). Postservice identity has been associated with later personal adjustment, in particular, veterans who served in combat (Smith and True 2014). Aldwin et al. (1994), for example, reported that World War II and Korean War veterans who view their military experiences positively and as having desired effects (e.g., teaching them to cooperate, cope with adversity) express fewer posttraumatic stress symptoms than those who do not see military experiences as having positive effects.

Homelessness. A persistent topic for veterans has been over-representation among the homeless. According to estimates, about $11 \%$ of the homeless in the USA are veterans (Department of Housing and Development and Department of Veterans Affairs 2014). Homeless veterans are concentrated predominately in major urban areas, such as Los Angeles or New York City. Homeless veterans, when compared to nonveterans, tend to be male, older in age, and being high school graduates (Tsai et al. 2012). Homeless veterans also are more likely to be white and having a disability than nonveterans (Department of Housing and Development Urban Development 2010). Difficulties in adjusting to civilian life after military service may be one reason for veteran homelessness (Carillo et al. 2012), in addition to higher unemployment (Wood 2014) and greater prevalence of psychological conditions, especially among recent veterans (Tanielian and Jaycox 2008). However, reliable data on homeless veterans has been difficult to obtain, and some researchers dispute the prevailing assumption that more veterans than expected are homeless (Jones et al. 2014).

Veteran employment. Due to training and experiences, veterans often have been sought after for employment. Veterans already have job experience and tend to be older and more mature. Moreover, military occupations are often transferrable to civilian occupations saving time in training, for example, medics, mechanics, communications, etc. Veterans have demonstrable training and work performance in the form of standardized evaluations. Indeed, veterans perform at higher levels, have lower turnover rates after the first job, and advance more rapidly in Federal civil service organizations (Pollak et al. 2019). They, too, are desired because of their experiences as having followed protocols and direction by supervisors and having supervised others. Veterans having experienced organizational life are accustomed to organizational protocol and loyalty and have experiences with leadership and teamwork and the difference these areas make in a work setting.

Civic engagement. A recurrent research interest has been civic involvement of veterans. Studies show veterans, compared to nonveterans, participate more in community affairs and volunteer for community improvement. Some speculate veterans are more motivated by concern for the public good or humanity as a whole and consequently more involved in civic activities than nonveterans (see Griffith 2020). This argument goes back as far as the classic American Soldier studies. Here, Stouffer et al. (1949) documented the deep civic engagement of World War II veterans after returning home, contending that military service made veterans more concerned about others. Indeed, several studies present evidence of 
greater civic involvement among military veterans (Nesbit and Reingold 2011; Teigen 2006; Wilson and Ruger 2008).

Veteran identity. Another topic of investigative focus has been how veterans see themselves and how society sees them. Many veterans see themselves as being patriotic - having responded to a "call to duty" and served the country. Indeed, the primary reason enlistees report that they participated in the military was "to serve my country" (Helmus et al. 2018). Veterans usually take much pride in having served and having supported basic values of the society through military service (Helmus et al. 2018). Ironically, some ex-military servicemembers view themselves as no different from others, as evident from Burdett et al.'s (2012) study of UK veterans. To gather information, the researchers gathered responses of some 200 UK armed forces personnel by way of a structured telephone interview survey. Only half of those ex-service personnel surveyed described themselves as veterans, perhaps reflecting a disparity in what is a veteran between the UK government's official definition and that of the veteran community. Burdett et al. (2012) report that "neither older, nor longer-serving veterans nor those who had deployed or seen combat were significantly more likely to self-identify as veterans, suggesting that definitions based around historical deployments are less influential among veterans" (p. 754).

What are society's views of veterans? Military veterans, often having made sacrifices during wars, are generally respected and treated with deference by members of society. This treatment varies from country to country. In the UK and USA, veterans are honored on Remembrance Day and Veterans Day, respectively. Treatment is often particular to the wars in which veterans participated. For example, in the USA, Vietnam War veterans were often degraded - booed, spat on, etc., whereas veterans of the recent OIF and OEF were praised and admired. The UK has a rich historical tradition of relying on regimental and corps associations as well as veterans charities to provide support to veterans, for example, the well-established Soldiers, Sailors, Airmen and Families Association (founded in 1885), Combat Stress (founded in 1919 and originally named the Ex-Servicemen's Welfare Society), the Royal British Legion (founded in 1921). Many veterans doubt civilians can understand their military experiences (Ahern et al. 2015). Indeed, military veterans often have reported problems forming and maintaining relationships with civilians following discharge (Olsen et al. 2014). While civilians desire to express gratitude for their service by sayings, "Thank you for your service," many veterans view this phrase as superficial and ingratiating toward veterans (Horton 2013). Detached from veterans' experiences, in particular, trauma experienced by combat veterans, veterans consider these comments as disingenuous.

\section{How to Study Reservists and Veterans}

This section describes directions and major challenges for future research when studying reservists and veterans. First, we provide a summary of the topic areas or themes of reservist and veteran studies, identifying commonalities and gaps. These provide direction for content of future studies on these populations. Next, we then 
describe methodological approaches to studying reservists and veterans, emphasizing past and current challenges. These are useful considerations for future studies.

\section{Substantive Scope of the Field}

Table 1 displays a summary of investigative topic areas or themes for reservists and veterans.

Noteworthy is that investigative topics for reservists centers on within-service experiences, such as deployment and contemporary demands of reserve military service, and how these experiences impact reservists' readiness, retention, and recruitment; family life; and health. In contrast, the investigative focus for veterans centers on how within-service experiences, especially combat exposure, impact later life, examining aspects of transitions from military life to civilian employment, family, and later health. Even so, many of the topic areas overlap for reservists and veterans, specifically health and transition issues. For both groups, much of the current research focuses largely on trauma experienced during recent wars. For many countries, the conflicts in Iraq and Afghanistan resulted in the largest deployments of reservists since World War II. For reservists, health has been examined after having returned from deployment. By comparison, health of veterans has been examined

Table 1 Summary of investigative topic areas or themes for reservists and veterans

\begin{tabular}{|c|c|c|}
\hline $\begin{array}{l}\text { Topic area/ } \\
\text { theme }\end{array}$ & Reservists & Veterans \\
\hline Readiness & $\begin{array}{l}\mathbf{X} \text { - related to changed role of reserve } \\
\text { force and the organizational dynamics } \\
\text { of a total force }\end{array}$ & Not applicable \\
\hline $\begin{array}{l}\text { Well-being/ } \\
\text { Health }\end{array}$ & $\begin{array}{l}\mathbf{X}-\text { deployment adjustments and } \\
\text { postdeployment }\end{array}$ & $\begin{array}{l}\mathbf{X}-\text { most interest in long after } \\
\text { departing military service and } \\
\text { in-service and preservice predictors of } \\
\text { well-being/health }\end{array}$ \\
\hline Family & $\begin{array}{l}\mathbf{X} \text { - related deployment adjustment, } \\
\text { postdeployment reintegration and the } \\
\text { day-to-day negotiations of part-time } \\
\text { reserve service }\end{array}$ & $\begin{array}{l}\mathbf{X} \text { - related to dealing with poor well- } \\
\text { being/health of veteran in the family }\end{array}$ \\
\hline $\begin{array}{l}\text { Civilian } \\
\text { employment }\end{array}$ & $\begin{array}{l}\mathrm{X} \text { - relative to resuming civilian } \\
\text { employment after deployment and the } \\
\text { day-to-day negotiation of part time } \\
\text { reserve service }\end{array}$ & $\begin{array}{l}\mathbf{X} \text { - relative to obtaining civilian } \\
\text { employment after having served full- } \\
\text { time in military }\end{array}$ \\
\hline $\begin{array}{l}\text { Civic } \\
\text { engagement }\end{array}$ & & $\begin{array}{l}\mathbf{X} \text { - voting, participation in political } \\
\text { causes, community service }\end{array}$ \\
\hline Recruitment & $\begin{array}{l}\mathbf{X} \text { - related to why people volunteer to } \\
\text { be a reserve }\end{array}$ & Not applicable \\
\hline Identity & $\begin{array}{l}\mathbf{X}-\text { related to change role of reserve } \\
\text { force; identities compatible with new } \\
\text { demands and potential identity clashes } \\
\text { with full-time military service }\end{array}$ & $\begin{array}{l}\mathbf{X} \text { - readjusting identity of military } \\
\text { member to civilian }\end{array}$ \\
\hline
\end{tabular}


much later after they leave military service and often in relation to other veteran concerns, such as homelessness, unemployment, and suicide.

Transition from full-time military service has been an interest for both reservists and veterans. For veterans, the transition interest has usually been after several years of active duty, perhaps 1-2 enlistments, when they left full-time military service and enter civilian life. Reserve transition issues pertain mainly to returning to part-time military service and having to resume their familial role and civilian job. For reservists, these latter aspects may either ease or worsen transition. In terms of ease, previous roles provide a ready way to resume civilian life. In terms of hindrance, past roles may have changed for the reservist due to time spent away, deployment experiences, etc., and the reservist is unable to perform roles as he/she had once performed. Veterans, after spending years in the military, leave the military culture and the identity it provided. This process is unlike reservists, who have been deployed and then return to military service part-time still having some identity associated with military service.

Identity as a topic pertains to both reservists and veterans. The interest for reservists is an identity which is optimally compatible with the demands of military service. For veterans, the interest is having had an identity that no longer has a military context, once having left the military. Several studies relate this loss to transition problems.

Topics of recruitment, retention, and readiness have largely been interests for reservists, due to their current military service, and more recently, national defense's increased reliance on reservists. Civic engagement has been largely a topic of veterans, comparing veterans to nonveterans in voting and community involvement. It is likely that factors associated with civic engagement among veterans operate similarly among reservists. Both groups serve voluntarily for the benefit of others. Characteristics of people making them especially suited for employment has been largely studied among veterans. Since both groups served in the military, it likely that reservists would have similar desirous characteristics for employment. Civic engagement and advantages of hiring servicemembers might be topics for future research for reservists, making comparisons to findings found for veterans.

\section{Methodological Approaches and Challenges}

\section{Studying Reservists}

Major challenges to research on reservists are: human subjects review approval; gaining access to units; and getting unit members to participate in studies. The first hurdle is getting permission to access reservists for data collection. Access involves gaining the necessary permissions from the military, usually through the military ethical and review boards, commonly called Institutional Review Boards (IRBs). These boards consider medical and other potentially controversial research topics, often requiring detailed and lengthy review between one to six months not including the extremely time-consuming preparatory study application (Roberts 2016). Once approved, research staff must gain access to reservists. Most research studies 
involve gathering data from individual servicemembers. Considerable effort must be devoted to developing good relations with commanders of units in which reservists reside. Due to part-time military service, reservists' time is limited; commanders often choose training over other activities, such as research.

While all members of a unit may be considered for data collection, usually some form of sampling is used (see Griffith 2014). Many reserve units are spread geographically, making coordination, access, and travel difficult. This is why sampling based on clustering (or cluster sampling) is efficient. Reservists are clustered by unit, so frequently researchers randomly select units, and within units, select individual reservists. Careful thought about the population of interest dictates more specific targeting of reserve units and unit members for participation, for example, readiness of combat arms units, satisfaction of junior-ranking enlisted reservists, retention intentions of mid-level officers' retention intentions, etc. Once reserve units are identified for the study, several other factors come into play, crucial to the representativeness of the study findings. Once in the unit, reservists are available only at certain times in units, often weekends and evenings. Not all reservists in the unit necessarily attend the same training event. Thus, researchers must be flexible; repeat visits may be necessary.

Representativeness of study findings is a recurrent issue, in particular, for audiences receiving study results. For example, military leaders and policymakers are often skeptical of studies of small sample sizes, having little or no demonstrable representativeness indicators (e.g., comparing demographic characteristics of members in the sample to those of the population). Similar to most research on institutions, those most likely to agree to take part in research tend to be older, male, and of higher rank. Thus, there is a risk of response bias from the respondents with reserve officers and senior sergeants proportionately more likely to respond to participation than those in lower ranks. This can be mitigated after data collection through statistical weighting by rank and other factors such as practiced in the large-scale UK annual reservist survey (U.K. Defence Statistics 2019a). A more direct and simple way to address concerns about representativeness is comparison of demographic characteristics of the sample to those of the population. Often population demographic data are not very accessible and require some negotiation to achieve. This can be due to a combination of unreliable record keeping for reservists, data access restrictions, and national security requirements.

Data collection pertains to what kind of data is gathered and by what method. Kind of data refers to quantitative or qualitative data. Qualitative data are responses obtained from less structured questions and response categories than quantitative data. Qualitative data are often obtained from in-depth interviewing. Such interviews start with a few broad questions (e.g., recount the sequence of deployment experiences) and then followed up by more detailed questions (e.g., detail specific events of deployment). Responses are recorded verbatim with a few interpretative notes. Quantitative data are responses provided to the same question with defined response categories, for example, "Do you intend to re-enlist?," "No," "Maybe," or "Yes." What kind of method refers to how information from reservists is obtained, for 
example, through survey questionnaires administered in-person, by mail, or by Internet. Personal interviews and observations are also ways to gather data from reservists, usually yielding qualitative data. The method of data collection has much to do with optimizing participation as well as the content of information to be obtained - whether in-depth interviews which are more suited to personal open-ended questions; or whether population estimates on specific issues which are more suited to large-scale closed ended questionnaires.

A popular method for obtaining quantitative data from reservists is the survey. The amount of effort to develop the content (both questions and close-ended responses) for topics should not be underestimated (see Griffith 2014). Researchers can expect to spent considerable time developing questions - reviewing past questionnaires for appropriate content, performing literature reviews of the topics being investigated, and conducting individual or group interviews to explore content. Surveys are often quick to administer and can be completed in a variety of locations including the barracks, in the field, and solitary settings using the Internet or responding to questions on the telephone. More recently, online surveys have been very popular. Online surveys potentially offer more access to reservists and, thus, higher levels of participation. Online surveys do not require material copies, travel to units, and scheduling specific times. However, response rates for survey questionnaires, especially those online or not having direct supervision during administration are quite low. For example, the UK's Ministry of Defence annual attitude survey achieves about $40 \%$ completion rate for full-time personnel and $30 \%$ completion rate for reservists (U.K. Defence Statistics 2019b, c).

Methods that yield qualitative data have become more prevalent in recent years for studying reservists. Such methods typically use open-ended questions, broad in scope. Reservists' responses are then followed up by more specific questions pertinent to the study aims. Researchers summarize responses as recurrent themes, called thematic analysis (Braun and Clarke 2006). Thematic analysis is used in qualitative research and is especially suited for understanding events experienced by study participants. Focusing on themes or patterns of meaning in the data, it "reports experiences, meanings and the reality of participants, or it can be a constructionist method, which examines the ways in which events, realities, meanings, experiences and so on are the effects of a range of discourses operating within society" (Braun and Clarke 2006, p. 81). Qualitative data are particularly valuable for an under-researched topics and groups, such as reservists, where little is known or understood about the social phenomenon or group under investigation, or where the topic of investigation covers sensitive or complex issues, such as reintegration of reservists' family members (Future Reserves Research Programme 2018). Detailed knowledge of reservist policies and practices is very useful for interpreting data generated accurately.

Unlike quantitative data, qualitative data do not seek statistical representation of a population. Qualitative data rely on purposive sampling to reach "saturation." This refers to the point where no new themes are being generated in the data collected, suggesting that the range of everyday experiences has been captured and generally requires much smaller samples than methods of quantitative data. Of note, however, is that policymakers are sometimes skeptical of qualitative data due to 
limited sampling. The challenge for researchers is to demonstrate the utility of interpretations relying on qualitative data for more general policy or decision making. Recent approaches to synthesizing and presenting qualitative data can be useful in overcoming some of these issues (see Lewin et al. 2018).

As noted in the summary of studies, families and employers of reservists have been a focus of research. A number of studies have investigated reserve families and employers with varying degrees of success over the years for these reasons, though they remain under-studied aspects of reserve military service (Gribble et al. 2020). More recently, interest in families and civilian work has increased. This interest is due to reserve military service increasingly exacting costs from the families or civilian work, and both families and employers are heavily impacted by reservists' time away on deployments. Families or civilian work can also be barriers to retention for reservists. Gaining access to reservists' families is difficult often even more than access to fulltime servicemembers' families. Reserve family members and employers are often not listed in any formal database, so the source comes directly from reservists. If such information exists, it is usually not complete or unreliably recorded. Other factors make families and employers difficult to access. Both are geographically dispersed; members of each often do not visit military facilities, if at all. Unlike fulltime servicemembers, reserve family members do not necessarily identify as a military family but may think of themselves instead as having a member of the family in the military (Connelly et al. 2017). As such, reservist family members are much less integrated and tend to feel quite distant from the military. As a result, calls to take part in military-oriented research may not seem relevant to them.

Recruitment of reservist families via the Internet may prove a more successful access tactic for some projects. However, reservists' family members who do take part in Internet-based research often have particular reasons for involvement, including attempts to convince the researchers to advocate with the military on their behalf over personal issues. When reservists have been deployed to an operational theatre and return home after a considerable period, the family usually needs time for readjustments. And while this period can be of great interest to the researcher, reminders of the recent deployment in the form of a research project may need particular sensitivity on the part of the researcher to ensure family participation.

Access to civilian employers of reservists is also fraught with difficulty, as well. Reservists frequently are anxious about highlighting their reserve military service to an employer, being apprehensive about time away from civilian work being seen negatively (Cunningham-Burley et al. 2018). While this perception may not be justified, researchers need to be very careful in their approach. One approach has been contacting employers directly for opinions on reserve military service more generally. However, many employers have very little knowledge of reserve military service, given the wide distribution of reservists in employment. Often such broadbased requests from employers by researchers often end up on the desk of their only reservist. 


\section{Studying Veterans}

Approaches and challenges to research on reservists generally apply to research on veterans. Approaches to performing research on reservists, specifically, review, access, and participation, are similar to performing research on veterans. There is, however, some degree of variance. Unlike reservists, veterans usually are not organized as structured groups. As a result, review boards (IRBs) or convenient ways to obtain study participants are not readily available. For instance, even if veterans participate in organized ways (e.g., motorcycle enthusiasts; Moelker 2014), there is unlikely an IRB for such groups. Even so, in these cases, it is advisable to have some IRB review and approve the research plan. Also, organizations to which the researchers belong may require such reviews, for example, the American Psychological Association for psychological research. Some countries do have lists of veterans, albeit access is limited and requires extensive justification and review at various levels in the government. Too, such lists may have dated information on veterans, veterans who left military service many years ago. In the absence of such lists and formal organizations of veterans, access to veterans and subsequently their recruitment for study participation is difficult.

One approach to developing groupings of veterans is to identify groups in which veterans cluster, such as American Legion, Veterans of Foreign Wars, Elks Club, etc. Researchers will have to persuade organizational leaders of study merits in order to gain support of the proposed study by announcements to members and perhaps even by providing a list of members. Researchers then can develop a plan for sampling members. Veteran welfare organizations and charities can provide links into the veteran community. However, these organizations often serve veterans who are in need of help, and this can bias those participating in the study and study findings. A call for veterans to engage in research (e.g., newspaper ads, radio and television announcements, etc.) also risks over-representation of veterans who are advocates for their cases against the military. Finally, without a military context to legitimate and to support the study, trust in studies of veterans is paramount, especially for those veterans who had negative experiences in the military (Kilshaw 2006). Researchers would then have to devise methods to gain trust of potential study participants (see Moelker 2014).

Approaches and challenges to data collection concerning the kind of data gathered and the method of data collection for veterans are similar to those for reservists. The research literature has many examples of research on veterans, which provide successful methods of access, sampling, and recruitment, in addition to data collection methods and measures. An early example is the Veterans Affairs Normative Aging Study (NAS) from 1963 to 2014. This study followed 2000 or so male veterans of WWII and Korea (Mroczek and Spiro 2005). More recently, the USA initiated the Millennium Cohort Study in 2001 shortly before the Iraq and Afghanistan wars and thereafter (Smith et al. 2008). Military personnel reported on their new onset and persistent symptoms of PTSD after deployment in addition to their combat exposure. In 2003, the UK started a study of similar design, called the Kings College London Military Cohort study (Hotopf et al. 2006). These studies have proved very useful in establishing baseline data on veterans' mental health and 
other important indicators over time. Investigators are able to track changes and examine predictors of outcomes of interest before the veteran leaves military service. A particular note is that researchers devising future studies can often inquire about gaining access to these studies' documentation (e.g., sampling design, data collection methods, measures, etc.) and actual data for their own research questions. These resources can be enormously useful and time-saving.

\section{Summary}

This chapter offers a snapshot of reservists and veterans - who they are, what have been research topics and findings, and considerations when investigating members of the two groups. Past and current investigative topics and findings offer topics for future research, in addition to methodological approaches and challenges.

\section{Cross-References}

Civil-Military Relations?

Civil Military Relations: What is the State of the Field?

Dynamic Intersection of Military and Society

Military Personnel

Strategy and Doctrine

\section{References}

Ahern, J., Worthen, M., Masters, J., Lippman, S. A., Ozer, E. J., \& Moos, R. (2015). The challenges of Afghanistan and Iraq veterans' transition from military to civilian life and approaches to reconnection. PLoS One, 10(7), e0128599.

Aldwin, C. M., Levenson, M. R., \& Spiro, A. (1994). Vulnerability and resilience to combat exposure: Can stress have lifelong effects? Psychological Aging, 9, 34-44.

Armed Forces Annual Report. (2019). Försvarsmaktens årsredovisning 2018, bilaga 1-3 (Armed forces annual report 2018, annex 1-3). Stockholm: Försvarsmakten.

Ashcroft, M. (2014). The veterans' transition review. Retrieved December 10, 2014 from http:// www.veteranstransition.co.uk/vtrreport.pdf

Ben-Ari, E. (1989). Masks and soldiering: The Israeli Army and the Palestinian uprising. Cultural Anthropology, 4(4), 372-389.

Bohnert, A. S., Valenstein, M., Bair, M. J., Ganoczy, D., McCarthy, J. F., Ilgen, M. A., \& Blow, F. C. (2011). Association between opioid prescribing patterns and opioid overdose-related deaths. Journal of the American Medical Association, 305(13), 1315-1221.

Braun, V., \& Clarke, V. (2006). Using thematic analysis in psychology. Qualitative Research in Psychology, 3(2), 77-101.

Burdett, H., Woodhead, C., Iversen, A. C., Wessely, S., Dandeker, C., \& Fear, N. T. (2012). Are you a Veteran? Understanding of the term "veteran" among UK ex-service personnel: A research note. Armed Forces and Society, 39(4), 751-759.

Burkhart, L., \& Hogan, N. (2015). Being a female veteran: A grounded theory of coping with transitions. Social Work in Mental Health, 13(2), 108-127. 
Bury, P. (2019). Mission improbable: The transformation of the Army Reserve. Havant: Howgate.

Carafano, J. J. (2005). Total Force and the Abrams doctrine: Unfulfilled promise, uncertain future. Philadelphia: Foreign Policy Research Institute. http://www.fpri.org/enotes/20050203.military. carofano.totalforcepolicyabramsdoctrine.html

Carillo, E. V., Costello, J. J., \& Ra, C. Y. (2012). Homelessness among veterans. In A. Ruben, E. L. Weiss, \& J. E. Coll (Eds.), Handbook of military social work (pp. 247-270). Somerset: Wiley.

Clever, M., \& Fisher, K. L. (2017). Women as veterans. In L. Hicks, E. L. Weiss, \& J. E. Coll (Eds.), The civilian lives of U.S. veterans: Issues and identities (Vol. 1, 2, pp. 553-576). Santa Barbara: Praeger.

Connelly, V. (2019, June). Understanding and explaining the tensions between full time Regulars and part time Reserves within the British Army. "Transmigrants are not welcome here?" In Ben-Ari, E. (chair), Total defence workforce - Reservists as transmigrants (Part I). Symposium conducted at the European Research Group on Military and Society (ERGOMAS). Lisbon: University Institute of Lisbon.

Connelly, V., \& Burgess, M. (2013). Suicide among Falkland war veterans - Understanding why misleading "sound bites" about veterans are more believable than "sound statistics." (Rapid Response) British Medical Journal. http://www.bmj.com/content/346/bmj.f3204/rr/677045

Connelly, V., Fear, N., Morrison, Z., Hennelly, S., \& Smith, J. (2017). Support to the families of reservists: An investigation of needs, current provision, and gaps final report. London: Defence Human Capability Science \& Technology Centre (DHCSTC).

Cooper, L., Caddick, N., Godier, L., Cooper, A., \& Fossey, M. (2018). Transition from the military into civilian life: An exploration of cultural competence. Armed Forces and Society, 44(1), 156-177.

Cunningham-Burley, S., Tindal, S., Morrison, Z. \& Connelly, V. (2018, June). Negotiating civilian $\&$ military lives: How reservists manage their military service, families and civilian work. FRRP project briefing 1. Future Reserves Research Programme. http://www.future-reserves-research. ac.uk/wp-content/uploads/2018/07/FRRP-project-briefing-1-Negotiating-civilian-and-militarylives.pdf

Dandeker, C., Eversden-French, C., Greenberg, N., Hatch, S., Riley, P., van Staden, L., \& Wessely, S. (2010). Laying down their rifles: The changing influences on the retention of volunteer British Army Reservists Returning from Iraq, 2003-2006. Armed Forces and Society, $36(2), 264-289$.

Department of Housing and Development and Department of Veterans Affairs. (2014). The 2014 Annual Homeless Assessment Report (AHAR) to Congress, Part 1, Point-in-time assessments of homelessness. Washington, DC: HUD and VA.

Department of Housing and Development and Urban Development. (2010). Veteran homelessness, a supplemental report to the 2009 annual homeless assessment report to congress. Washington, DC: HUD and VA.

Disabled American Veterans (DAV). (2014). Women veterans: The long journey home. Retrieved from http://www.dav.org/women-veterans-study/

Drew, N. S. (1999). NSC-68: Forging the strategy of containment. Washington, DC: National Defense University Press, NSC-20/4, Sec. 21 (a), 31. Retrieved November 4, 2009 from http:// handle.dtic.mil/100.2/ADA432148. Accessed 4 Nov 2009.

Erbes, C. R., Arbisi, P. A., Courage, C., Polusny, M. A., Thuras, P., \& Rath, M. (2008). Contextual predictors of post-deployment symptoms in the RINGS study. Paper presented at the annual meeting of the 2008 American psychological convention, August 14-17, 2008, Boston.

Fear, N. T., Jones, M., Murphy, D., Hull, L., Iversen, A. C., Coker, B., .. Wessely, S. (2010). What are the consequences of deployment to Iraq and Afghanistan on the mental health of the UK armed forces? A cohort study. Lancet, 375(9728), 1783-1797.

Federal Research Division. (2019). Reports prepared for the Commission on the National Guard and Reserves. Washington, DC: Library of Congress. https://www.loc.gov/rr/frd/CNGRreports.html 
Future Reserves Research Programme. (2018). FRRP information sheet - Qualitative research and numbers of research participants. Retrieved from http:/www.future-reserves-research.ac.uk/wpcontent/uploads/2018/07/FRRP-information-sheet-qualitative-research-and-numbers-ofresearch-participants.pdf

Gallaway, M. S., Bell, M. R., Lagana-Riordan, C., Fink, D. S., Meyer, C. E., \& Millikan, A. M. (2013). The association between U.S. Army enlistment waivers and subsequent behavioral and social health outcomes and attrition from service. Military Medicine, 178, 261-266.

General Accounting Office. (1992). Operation Desert Storm: Army Guard combat brigade war lessons reflect longstanding problems (Testimony, GAO/T-NSIAD-92-36). Washington, DC: General Accounting Office.

Goffman, E. (1961). Asylums: essays on the social situation of mental patients and other inmates. New York: Anchor Books.

Governing (2017). Military active-duty personnel, Civilians by state. Retrieved September, 2017 from https://www.governing.com/gov-data/public-workforce-salaries/military-civilian-activeduty-employee-workforce-numbers-by-state.html

Gribble, R. et al. (2020). Are we family? A scoping review of how military families are defined in mental health and substance use research. Journal of Military Veteran and Family Health. https://doi.org/10.3138/jmvfh.CO19-005

Griffith, J. (1995). The Army Reserve soldier in Operation Desert Storm: Perceptions of being prepared for mobilization, deployment and combat readiness. Armed Forces and Society, 21(2), $195-215$.

Griffith, J. (2008). Institutional motives for serving in the U.S. Army National Guard: Implications for recruitment, retention, and readiness. Armed Forces and Society, 34(2), 230-258.

Griffith, J. (2010). Citizens coping as soldiers: A review of postdeployment stress symptoms among deployed reservists. Military Psychology, 22, 176-206.

Griffith, J. (2011b). Reservists' identities: What are they, and do they matter? An empirical examination. Armed Forces and Society, 37(4), 619-635.

Griffith, J. (2012). Suicide in the Army National Guard: An empirical inquiry. Suicide and Life-Threatening Journal, 42(1), 104-119.

Griffith, J. (2015). Homecoming of soldiers who are citizens: Re-employment and financial status of returning OIF/OEF Army National Guard soldiers. Work, 50, 85-96. Eds: (K. Jacobs \& R. Wolf).

Griffith, J. (2019). Family readiness groups: Helping deployed Army National Guard soldiers and their families. Journal of Community Psychology, 48(3), 804-817.

Griffith, J. (2020). Community service and voting among veterans and nonveterans using a national sample of college undergraduates. Armed Forces and Society, 46(2), 323-341.

Griffith, J., \& Bryan, C. J. (2017). Timing of suicide and associated risk factors following deployment of U.S. Army National Guard soldiers. Military Psychology, 29(3), 202-215.

Griffith, J., \& Perry, S. (1993). Wanting to soldier: Enlistment motivations of Army Reserve recruits before and after Operation Desert Storm. Military Psychology, 5(2), 127-139.

Grissmer, D. W., Kirby, S. N., \& Sze, M. B. (1992). Factors affecting reenlistment of reservists: Spouse and employer attitudes and perceived unit environment (Report no. R-4011-RA). Santa Monica: RAND.

Hatch, S. L., Harvey, S. B., Dandeker, C., Burdett, H., Greenberg, N., Fear, N. T., \& Wessely, S. (2013). Life in and after the armed forces: Social networks and mental health in the UK military. Sociology of Health \& Illness, 35(7), 1045-1064.

Helmus, T. C., Zimmerman, S. R., Posard, M. N., Wheeler, J. L., Ogletree, C., Stroud, Q., \& Harrell, M. C. (2018). Life as a private: A study of the motivations and experiences of junior enlisted personnel in the U.S. Army. Santa Monica: RAND.

Horton, H. (2013, November 10). Help veterans by taking them off the pedestal. The Atlantic Monthly. https://www.theatlantic.com/national/archive/2013/11/help-veterans-by-taking-themoff-the-pedestal/281316/ 
Jaffe, G. (2013, February 1). VA study finds more veterans committing suicide. The Washington Post. Retrieved from https://www.washingtonpost.com/national/2013/01/31

Jones, A., Quilgars, D., O'Malley, L. J., Rhodes, D., Bevan, M. A., \& Pleace, N. (2014). Meeting the housing and support needs of single veterans in Great Britain. Research Report. Centre for Housing Policy. York, U.K.: University of York.

Karsten, P., Feaver, P., \& Kohn, R. (2002). Soldiers and civilians: The civil-military gap and American national security. Journal of Military History, 66(3), 934-937.

Karstoft, K., Armour, C., Andersen, S. B., Bertelsen, M., \& Madsen, T. (2015). Community integration after deployment to Afghanistan: A longitudinal investigation of Danish soldiers. Social Psychiatric Epidemiology, 50(4), 653-660.

Kilshaw, S. (2006). On being a Gulf veteran: An anthropological perspective. Philosophical Transactions of the Royal Society, B: Biological Sciences, 361(1468), 697-706.

Kirby, S. N. (2000). The impact of deployment on the retention of military reservists. Armed Forces and Society, 26, 259-285.

Kline, A., Falca-Dodson, M., Sussner, B., Ciccone, D., Chandler, H., \& Callahan, L. (2010). Effects of repeated deployment to Iraq and Afghanistan on the health of New Jersey Army National Guard troops: Implications for military readiness. American Journal of Public Health, 100, 276-283.

Kulka, M., Rattray, N. A., \& Salyers, M. P. (2015). Mixed methods study examining work reintegration experiences from perspectives of Veterans with mental health disorders. Journal of Rehabilitating Research Development, 52(4), 477-490.

Larsson, G., Berglund, A. K., \& Ohlsson, A. (2016). Daily hassles, their antecedents and outcomes among professional first responders: A systematic literature review. Scandinavian Journal of Psychology, 57(4), 359-367. https://doi.org/10.1111/sjop.12303.

Larsson, G., Lundell, E., Svensén, S., Berglund, A. K., \& Nilsson, S. (2018a). Enskilt tjänstgörande 1990-2015: Hur mår de idag och vilken långsiktig effekt har vardagsstress? (Rapport Serie I, 111). Försvarshögskolan: Institutionen för säkerhet, strategi och ledarskap, Ledarskapscentrum.

Larsson, G., Lundell, E., Svensén, S., \& Nilsson, S. (2018b). Internationell tjänst 2011-2015: Hur mår dessa kvinnor och män idag och vilken långsiktig effekt har vardagsstress? (Rapport Serie I, 116). Försvarshögskolan: Institutionen för säkerhet, strategi och ledarskap, Ledarskapscentrum.

Lewin, S., Booth, A., Glenton, C., et al. (2018). Applying GRADE-CERQual to qualitative evidence synthesis findings: Introduction to the series. Implementation Science, 13(Suppl 1), $2,1-70$.

Lomsky-Feder, E., Gazit, N., \& Ben-Ari, E. (2008). Reserve soldiers as transmigrants: Moving between the civilian and military worlds. Armed Forces and Society, 34(4), 593-614.

MacDermid, S. M. (2006). Multiple transitions of deployment and reunion for military families. http://www.cfs.purdue.edu/mfri/DeployReunion.ppt

Michel, P.-O. (2005). The Swedish soldier and general mental health following service in peacekeeping operations. Uppsala: Acta Universitatis Upsaliensis.

Ministry of Defence. (2011). Future reserves 2020: The independent commission to review the United Kingdom's reserve forces. London: TSO.

Ministry of Defence. (2019). Population projections: UK armed forces veterans residing in Great Britain, 2016 to 2028. Bristol: Defence Statistics Health.

Mroczek, D. K., \& Spiro, A., III. (2005). Change in life satisfaction during adulthood: Findings from the veterans affairs normative aging study. Journal of Personality and Social Psychology, 88(1), 189-202.

Murphy, D., \& Turgoose, D. (2019). Childhood adversity and mental health in veterans seeking treatment for mental health difficulties: Comparisons with the general military population. Psychological Trauma: Theory, Research, Practice, and Policy. https://doi.org/10.1037/ tra0000538.

Nelson, H., Army, W. H., Jacobs, B., \& Bluhm, R. K. (2001). The Army. Westport: Levin, Hugh \& Lauter. 
Nesbit, R., \& Reingold, D. A. (2011). Soldiers to citizens: The link between military service and volunteering. Public Administration Review, 71, 67-76.

Olsson, A.-M., \& Olsson, S.-E. (2019). Swedish families' responses to military deployment. In R. Moelker, M. Andres, \& N. Rones (Eds.), The politics of military families: State, work organisations, and the rise of the negotiation household (pp. 253-266). New York: Routledge.

Olsen, T., Badger, K., \& McCuddy, M. D. (2014). Understanding the student veterans' college experience: An exploratory study. U.S. Army Medical Department Journal, 101-108.

Orvis, B. R., Shukiar, H. J., McDonald, L. L., Mattock, M. G., Kilburn, M. R., \& Shanley, M. G. (1996). Ensuring personnel readiness in the Army Reserve components (Report no. MR-659-A). Santa Monica: RAND.

Parrott, S., Albright, D. L., Dyche, C., \& Steele, H. G. (2019). Hero, charity case, and victim: How U.S. news media frame military veterans on Twitter. Armed Forces and Society, 45(4), 702-722.

Pethrus, C.-M., Johansson, M., Neovious, K., Reutfors, J., Sundström, J., \& Neovious, M. (2017). Suicide and all-cause mortality in Swedish deployed military veterans: A population-based matched cohort study. BMJ Open, 7(9), e014034.

Pew Research Center. (2011). The military-civilian gap: Fewer family connections. Pew Research Center, Social and demographic trends. Retrieved November 23, 2011 from https://www. pewsocialtrends.org/2011/11/23/the-military-civilian-gap-fewer-family-connections/

Pew Research Center. (2019). The American veteran experience and the post-9/11 generation. Retrieved September 10, 2019 from https://www.pewsocialtrends.org/2019/09/10/the-ameri can-veteran-experience-and-the-post-9-11-generation/

Pollak, M., Arshanapalli, B., \& Hobson, C. (2019). Business case for hiring military veterans/ reservists: Stock price performance of military friendly firms. Journal of Veterans Studies, 4(2), 52.

Rentz, E. D., Marshall, S. W., Loomis, D., Casteel, C., Martin, S. L., \& Gibbs, D. A. (2007). Effects of deployment on the occurrence of child maltreatment in military and nonmilitary families. American Journal of Epidemiology, 165, 1199-1206.

Richardson, L. K., Frueh, C., \& Acierno, R. (2010). Prevalence estimates of combat-related PTSD: A critical review. Australian New Zealand Psychiatry, 44(1), 4-19.

Roberts, S. A. G. (2016). DMS research and MODREC - A guide for potential researchers. Journal of the Royal Naval Medical Service, 102(2), 130-134.

Romantuk, M., \& Kidd, C. (2018). The psychological adjustment experience of reintegration following discharge from military service: A systemic review. Journal of Military and Veterans' Health, 26(2), 60-73.

Sayer, N. A., Noorbaloochi, S., Frazier, P., Carlson, K., Gravely, A., \& Murdoch, M. (2010). Reintegration problems and treatment interests among Iraq and Afghanistan combat veterans receiving VA medical care. Psychiatric Services, 61(6), 589-597.

Schell, T. L., \& Marshall, G. N. (2008). Survey of individuals previously deployed to OEF/OIF. In T. Tanielian \& L. H. Jaycox (Eds.), Invisible wounds of war: Psychological and cognitive injuries, their consequences, and services to assist recovery (pp. 87-161). San Monica: Rand Corporation.

Schmitz, E. J. (1990). The Army College Fund and military manpower: A review of existing research, technical report 1572. Alexandria: U.S. Army Research Institute for the Behavioral and Social Sciences.

Smith, R. T., \& True, G. (2014). Warring identities: Identity conflict and the mental distress of American veterans of the wars in Iraq and Afghanistan. Social Mental Health, 4(2), 147-161.

Spiegel, P. E., \& Shultz, K. S. (2003). The influence of preretirement planning and transferability of skills on naval officers' retirement satisfaction and adjustment. Military Psychology, 15(4), 285-307.

Stevelink, S. A., Jones, M., Hull, L., Pernet, D., MacCrimmon, S., Goodwin, L., .. Rona, R. J. (2018). Mental health outcomes at the end of the British involvement in the Iraq and Afghanistan conflicts: A cohort study. The British Journal of Psychiatry, 213(6), 690-697. 
Stouffer, S. A., Lumsdaine, A. A., Lumsdaine, M. H., Williams, R. M. Jr., Smith, M. B., Janis, I., . . Cottrell, L. S. Jr. (1949). The American soldier: Combat and its aftermath (studies in social psychology in World War II). Princeton: Princeton University Press.

Substance Abuse and Mental Health Services Administration. (2019). Critical issues facing veterans and military families. https://www.samhsa.gov/veterans-military-families/critical-issues.

Tanielian, T., \& Jaycox, L. H. (Eds.). (2008). Invisible wounds of war: Psychological and cognitive injuries, their consequences, and services to assist recovery. Santa Monica: RAND.

Taylor, M. A., Shultz, K. S., Spiegel, P. E., Morrison, R. F., \& Greene, J. (2007). Occupational attachment and met expectations as predictors of retirement adjustment of naval officers 1. Journal of Applied Social Psychology, 37(8), 1697-1725.

Thomas, J. L., Riviere, L. A., McGurk, D., Castro, C. A., \& Hoge, C.W. (2010). Prevalence of mental health problems and functional impairment among active duty component and National Guard soldiers 3 and 12 months following combat in Iraq. Archives of General Psychiatry, 67, 614-623.

Teigen, J. M. (2006). Enduring effects of the uniform: Previous military experience and voting turnout. Political Research Quarterly, 59, 601-607.

Tsai, J., Mares, A. S., \& Rosenheck, R. A. (2012). Do homeless veterans have the same needs and outcomes as non-veterans? Military Medicine, 171(1), 27-31.

Tsai, J., Link, B., Rosenheck, R. A., \& Pietrzak, R. H. (2016). Homelessness among a nationally representative sample of USA veterans: Prevalence, service utilization, and correlates. Social Psychiatric Epidemiology, 51(6), 907-916.

U.K. Defence Statistics. (2019a). Background quality report for the tri-service Reserves Continuous Attitude Survey (ResCAS). London: Defence Statistics (Surveys), Ministry of Defence, https:// assets.publishing.service.gov.uk/government/uploads/system/uploads/attachment_data/file/ 809631/20190620-Background_Quality_Report_for_ResCAS_2019.pdf

U.K. Defence Statistics. (2019b). U.K. regular armed forces continuous attitude survey results 2019. Defence Statistics (Surveys). London: Ministry of Defence. https://assets.publishing. service.gov.uk/government/uploads/system/uploads/attachment data/file/811689/Armed Forces_Continuous_Attitude_Survey_2019_Main_Report.pdf

U.K. Defence Statistics. (2019c). Reserves continuous attitude survey results 2019. Defence Statistics (Surveys). London: Ministry of Defence. https://assets.publishing.service.gov.uk/gov ernment/uploads/system/uploads/attachment_data/file/809626/20190620-ResCAS_Report_ 2019.pdf

U.S. Department of Defense. (2008). DoD announces new reserve component deployment support and reintegration office (News release no. 212-08). Washington, DC: Office of the Assistant Secretary of Defense (Public Affairs).

Vest, B. M. (2012). Citizen, soldier, or citizen-soldier? Negotiating identity in the U.S. National Guard. Armed Forces and Society, 39(4), 602-627.

Walker, D. (2012). Anticipating army exit: Identity constructions of final year UK career soldiers. Armed Forces and Society, 39, 284-304.

Weibull, L. (2009). "Vi borde också få medalj": Om stöd till militära familjer under utlandstjänstgöring (Serie T, 38). Stockholm: Försvarshögskolan.

Whitlock, J. E. (2006). How to make army force generation work for the Army Reserve component. Carlisle Barracks: Strategic Studies Institute, Army War College.

Wilson, S. E., \& Ruger, W. (2008). Warriors don't bowl alone: Military service and civic participation. Salt Lake City: Brigham Young University. Retrieved September 11, 2018 from https:// fhss.byu.edu/polsci/SiteAssets/pages/wilson/. . .Civic\%20Participation.doc.pdf

Wood, C. A. (2014). Unemployment continues its downward trend in 2013. Monthly Labor Review. 


\section{Recommended for Further Reading}

\section{Reserves, Overview}

Connelly, V. (2018). A history of the Army Reserve. Annex to the Army Reserve: A commanders guide. London: Ministry of Defence.

Cooper, L., Caddick, N., Godier, L., Cooper, A., \& Fossey, M. (2018). Transition from the military into civilian life: An exploration of cultural competence. Armed Forces and Society, 44(1), 156-177.

Griffith, J. (2011a). Decades of transition for the U.S. reserves: Changing demand on reserve identity and mental well-being. International Review of Psychiatry, 23, 181-191.

\section{Reserves, Deployment Issues}

Castaneda, L. W., Harrell, M. C., Varda, D. M., Hall, K. C., Beckett, M. K., \& Stern, S. (2009). Deployment experiences of guard and reserve families: Implications for support and retention. Santa Monica: National Defense Research Institute, Rand.

Griffith, J. (2015). Homecoming of soldiers who are citizens: Re-employment and financial status of returning OIF/OEF Army National Guard soldiers. Work, 50, 85-96. (Eds: K. Jacobs \& R. Wol).

Wilcox, S. L., Oh, H., Redmond, S. A., Chicas, J., Hassan, A. M., Lee, P., \& Ell, K. (2015). A scope of the problem: Post-deployment reintegration challenges in a National Guard. Work, 50, 73-83.

\section{Reserves, Health and Well-Being}

Griffith, J. (2010). Citizens coping as soldiers: A review of postdeployment stress symptoms among deployed reservists. Military Psychology, 22, 176-206.

Hotopf, M., Hull, L., Fear, N. T., Browne, T., Horn, O., Iversen, A., . . Greenberg, N. (2006). The health of UK military personnel who deployed to the 2003 Iraq war: A cohort study. The Lancet, 367(9524), 1731-1741.

Interian, A., Kline, A., Callahan, L., et al. (2012). Readjustment stressors and early mental health treatment seeking by returning National Guard soldiers with PTSD. Psychiatric Services, 63(9), $855-861$.

Milliken, C. S., Auchterlonie, J. L., \& Hoge, C. W. (2007). Longitudinal assessment of mental health problems among active and reserve component soldiers returning from the Iraq war. Journal of the American Medical Association, 298, 2141-2148.

Smith, T. C., Ryan, M. A. K., Wingard, D. L., Sallis, J. F., \& Kritz-Silverstein, D. (2008). New onset and persistent symptoms of posttraumatic stress disorder self-reported after deployment and combat exposure: Prospective population-based U.S. military cohort study. British Medical Journal, 336(7640), 366-371.

\section{Veterans: U.S. Cohort Descriptions; Issues of Transition, Families, Employment, Health, and Homelessness; Civic Engagement}

Hicks, L., Weiss, E. L., \& Coll, J. E. (Eds.). (2017). The civilian lives of U.S. veterans: Issues and identities (Vol. 1, 2). Santa Barbara: Praeger. 


\section{Studying Reserves and Veterans}

Griffith, J. (2014). Survey research in military settings. In J. Soeters, P. M. Shields, \& S. Rietjens (Eds.), Routledge handbook of research methods in military studies (pp. 179-193). London: Routledge.

Moelker, R. (2014). "Being one of the guys or a fly on the wall?" Participant observation of veteran bikers. In J. Soeters, P. M. Shields, \& S. Rietjens (Eds.), Routledge handbook of research methods in military studies (pp. 216-227). London: Routledge.

Open Access This chapter is licensed under the terms of the Creative Commons Attribution 4.0 International License (http://creativecommons.org/licenses/by/4.0/), which permits use, sharing, adaptation, distribution and reproduction in any medium or format, as long as you give appropriate credit to the original author(s) and the source, provide a link to the Creative Commons license and indicate if changes were made.

The images or other third party material in this chapter are included in the chapter's Creative Commons license, unless indicated otherwise in a credit line to the material. If material is not included in the chapter's Creative Commons license and your intended use is not permitted by statutory regulation or exceeds the permitted use, you will need to obtain permission directly from the copyright holder.

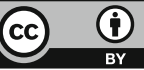

